\title{
Nonlinear Markov Chain Modelling of the Novel Coronavirus (Covid- 19) Pandemic
}

\section{Muammer Catak ${ }^{1}$ and Necati Duran ${ }^{2}$}

${ }^{1}$ College of Engineering and Technology, American University of the Middle East, Kuwait

${ }^{2}$ Department of Computer Engineering, Ege University, Izmir, Turkey

April 21, 2020

lmost all countries around the world are struggling against the novel coronavirus (Covid19) pandemic. In this paper, a nonlinear Markov chains model is proposed in order to analyse and to understand the behaviour of the Covid-19 pandemic. The data from China was used to build up the presented model. Thereafter, the nonlinear Markov chain model is employed to estimate the daily new Covid-19 cases in some countries including Italy, Spain, France, UK, the USA, Germany, Turkey, and Kuwait. In addition, the correlation between the daily new Covid-19 cases and the daily number of deaths is examined.

\section{Introduction}

The novel coronavirus (Covid-19) pandemic has been spread all over the world [12]. According to Coronavirus disease 2019 (COVID-19) Situation Report-82 published by WHO, the total number of infected people approached to 2 million. However, in the same report WHO states that the true-number of the infected people might be higher than the number of the confirmed cases. Many researched have been published in order to analyse and to understand the dynamics of the Covid-19 pandemic $[9,13,5,14,7,10,6]$. Guiliani et al. [8] proposed a multivariate time-series linear model in order to understand and estimate the spatio-temporal diffusion of the Covid-19 pandemic in Northern Italy. It is stated that the proposed model is capable of to predict with an error of $3 \%$ compared to the late available data in Italy. Kucharski et al. [11] developed a mathematical model to understand the early dynamics of the transmission of the Covid-19 pandemic. They divided the entire population into four subsets as; susceptible, exposed, infectious, and removed.

In this study a mathematical model based on nonlinear Markov chains is proposed in order to estimate of the daily new Covid-19 cases. The paper s organized as follows: In Section 2, materials and methods employed in the proposed model is presented. Results obtained from the model are depicted

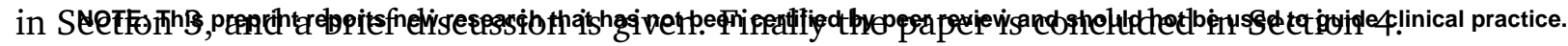


medRxiv preprint doi: https://doi.org/10.1101/2020.04.21.20073668; this version posted April 24, 2020. The copyright holder for this preprint (which was not certified by peer review) is the author/funder, who has granted medRxiv a license to display the preprint in perpetuity.

All rights reserved. No reuse allowed without permission.

Nonlinear Markov Chain Modelling of the Novel Coronavirus (Covid-19) Pandemic

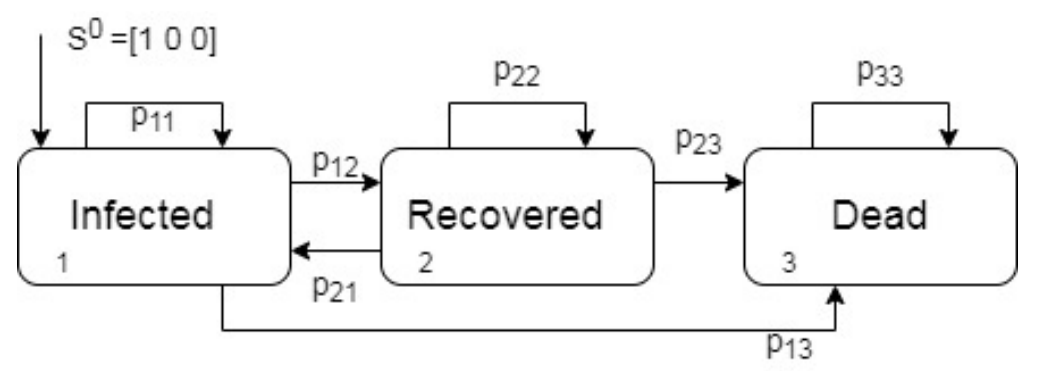

Figure 1: Illustration of the transition probabilities of the proposed model

\section{Materials and Method}

Let $S_{t}$ is a random process having countable number of states. If the process is in $i^{\text {th }}$ state at time $t$, then it will be in $j^{\text {th }}$ state at time $t+1$ with the propability of $p_{i j}$ defined as [4];

$$
\begin{aligned}
p_{i j} & =P\left\{S_{t+1}=j \mid S_{t}=i\right\} \\
& =P\left\{S_{t+1}=j\left|S_{t}=i\right| S_{t-1}=i_{t-1}\left|S_{t-\tau}=i_{t-\tau}\right| \ldots \mid S_{1}=i_{1}\right\}
\end{aligned}
$$

The state probability distribution vector $S(t)$, the transition time step $\tau$, and the transition matrix $P$ are the main parameters will be used in a Markov chain model. In this study, the states are defined as $i$ ) $1:=$ Infected, $i$ i) $2:=$ Recovered, $i$ ii) $3:=$ Dead. Thereafter, the nonlinear Markov cahin model can be expressed as [3];

$$
S_{t+1}=\left(S_{t}+S^{0}\right) P
$$

where $S_{t+1}$ is the next state probability distribution, $S_{t}$ is the current state probability distribution, $S^{0}$ is the new infected distribution, and $P=P\left(t, S_{t}\right)$ is the Markovian transition matrix. The transition probabilities of the proposed nonlinear Markov chains model between the states are illustrated in Figure 1. Since the state-3 is an absorbing state, $p_{33}$ is assigned as 1 . The remaining entries of the transition matrix $P$, i.e $p_{i j}$, have been calculated based on the confirmed daily number of Covid-19 cases and the daily test numbers of the corresponding countries.

The related website of John Hopkins University [2] has been used in order to get data in accordance with [1]. The number of the daily new cases, the number of Covid-19 test done, the number of the recovered cases, and the number of daily deaths have been used as the proposed model parameters affecting on the transition probabilities between the predefined states. The data obtained from China is employed to developed the model. The daily new Covid-19 cases and the corresponding estimation of the proposed nonlinear Markov chain model is illustrated in Figure 2. In China, the confirmed new daily Covid-19 cases on 11 February 2020, which is the $21^{\text {st }}$ day after the first case was reported on $22^{\text {nd }}$ January 2020, is assumed as a deviation from the model due to the test policy.

\section{Results and Discussion}

In this section, the proposed nonlinear Markov chain model is employed in order to estimate the daily new Covid-19 cases in Italy, Spain, France, UK, Germany, USA, Turkey, and Kuwait. Please note that, it is assumed that the Covid-19 pandemic is over if the number of the daily new Covid-19 cases are less than 50 considering 3 consecutive days apart from Kuwait where the threshold was taken as 10 instead of 50 considering the population of State of Kuwait.

The daily new Covid-19 cases of the aforementioned countries are shown in Figure 3 and Figure 4. The first Covid-19 case was reported in Italy on 22 February 2020. It seems the Covid-19 pandemic has reached its peak after almost 40 days from the first case was announced, then it started to decrease the number of the Covid-19 cases daily bases. The proposed model estimates that the Covid-19 pandemic will be over about the first week of May 2020 results in more than 200 thousands of the infected person. 
medRxiv preprint doi: https://doi.org/10.1101/2020.04.21.20073668; this version posted April 24, 2020. The copyright holder for this preprint (which was not certified by peer review) is the author/funder, who has granted medRxiv a license to display the preprint in perpetuity.

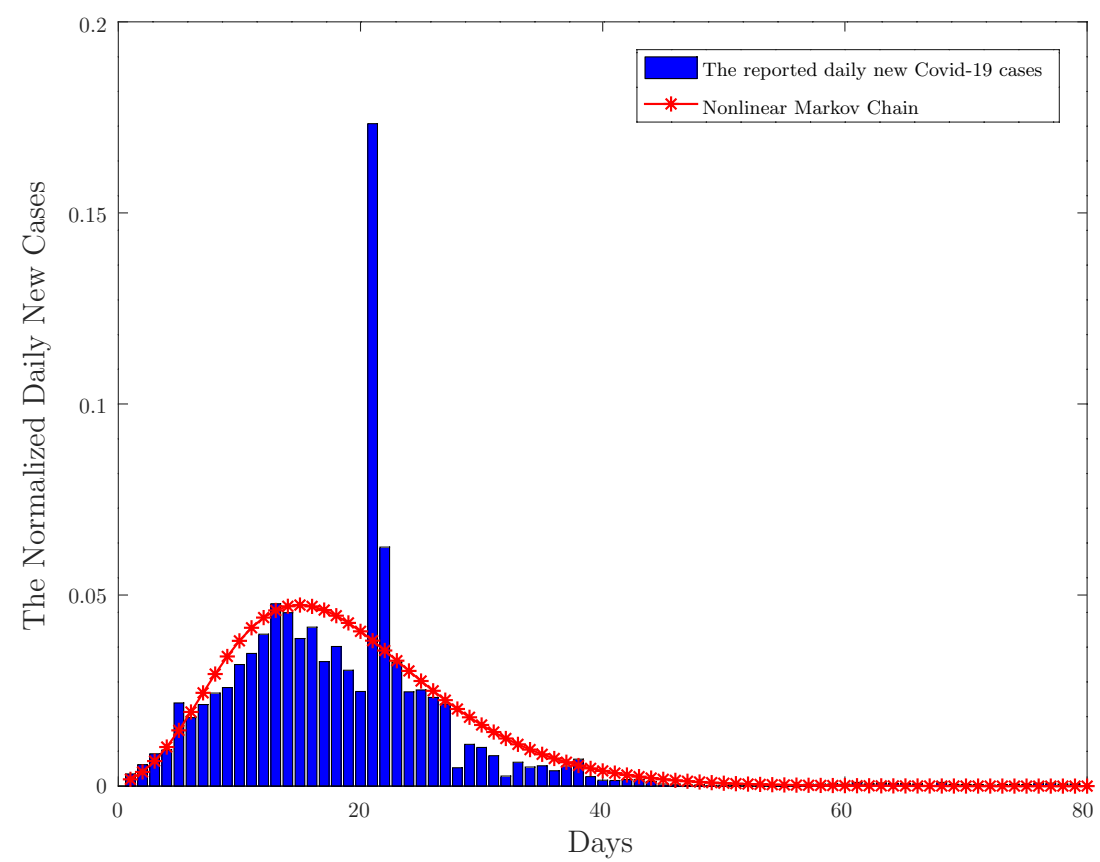

Figure 2: The daily reported new Covid-19 cases and the prediction of the proposed nonlnear Markov chain model

A detailed statistical information about the related countries are given in Table 1. In general, the first cases of the Covid-19 were reported about end February, 2020. Thereafter, the Covid-19 pandemic reached its peak values in the first half of April, 2020. Finally, the model estimates that the Covid-19 pandemic will be over before the first week of May, 2020.

Table 1: Estimations of the proposed Nonlinear Markov chains model for some countries

\begin{tabular}{|l||l|l|l|l|}
\hline Country & $\begin{array}{l}\text { First Case Re- } \\
\text { ported }\end{array}$ & Peak Date & $\begin{array}{l}\text { Estimation of } \\
\text { the End Date }\end{array}$ & $\begin{array}{l}\text { Estimation } \\
\text { of the Total } \\
\text { number of } \\
\text { Infected }\end{array}$ \\
\hline Italy & 22 February & 1 April & 4 May & 206.000 \\
Spain & 25 February & 5 April & 2 May & 228.000 \\
France & 26 February & 6 April & 5 May & 202.000 \\
UK & 28 February & 8 April & 3 May & 169.000 \\
Germany & 26 February & 4 April & 28 April & 174.000 \\
USA & 21 February & 4 April & 8 May & 975.000 \\
Turkey & 11 March & 12 April & 7 May & 138.000 \\
Kuwait & 24 February & 8 April & 10 May & 2.650 \\
\hline
\end{tabular}

Moreover, the correlation between the daily new Covid-19 cases and the daily number of deaths are analysed considering the corresponding countries. The number of $l a g-k$ where the cross correlation of the functions reaches its maximum are given in Table 2.

The cross correlation between two sequences can be explained as; 
medRxiv preprint doi: https://doi.org/10.1101/2020.04.21.20073668; this version posted April 24, 2020. The copyright holder for this preprint (which was not certified by peer review) is the author/funder, who has granted medRxiv a license to display the preprint in perpetuity.

All rights reserved. No reuse allowed without permission.

Nonlinear Markov Chain Modelling of the Novel Coronavirus (Covid-19) Pandemic

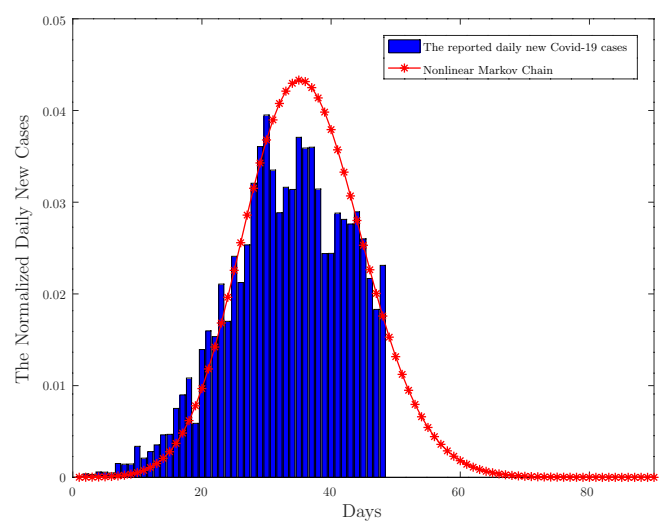

(a) Italy

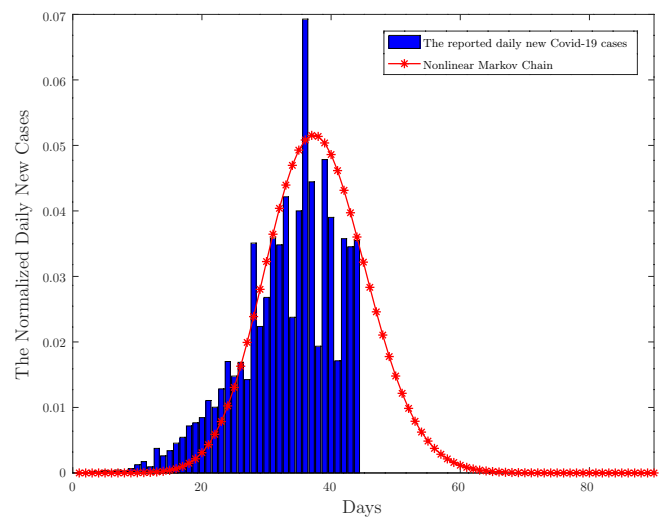

(c) France

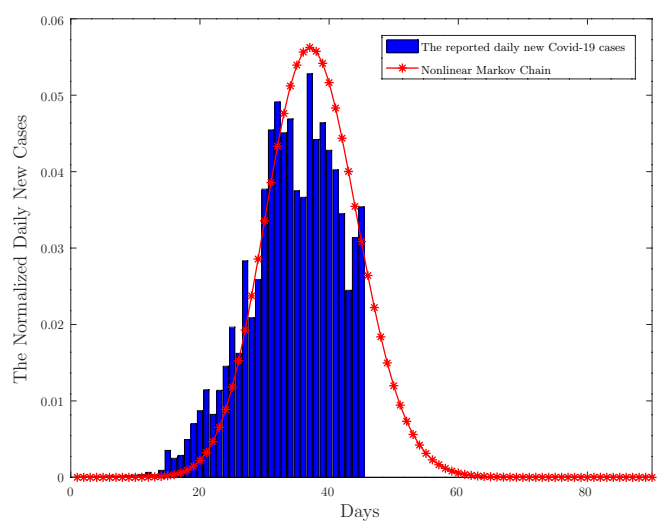

(b) Spain

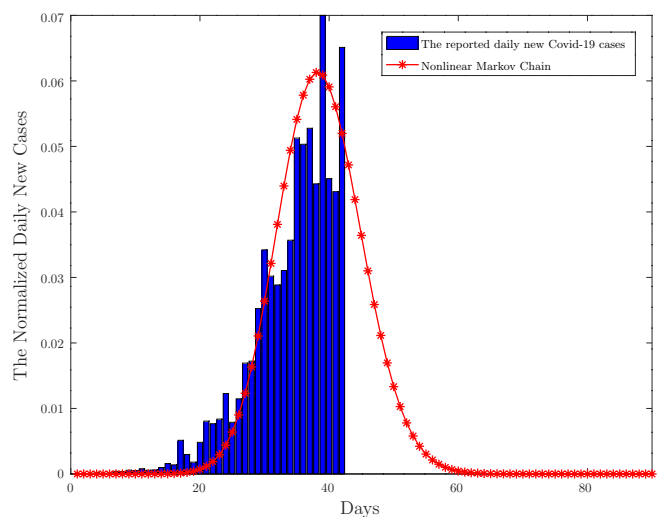

(d) $U K$

Figure 3: The daily number of new Covid-19 cases 
medRxiv preprint doi: https://doi.org/10.1101/2020.04.21.20073668; this version posted April 24, 2020. The copyright holder for this preprint (which was not certified by peer review) is the author/funder, who has granted medRxiv a license to display the preprint in perpetuity.

All rights reserved. No reuse allowed without permission.

Nonlinear Markov Chain Modelling of the Novel Coronavirus (Covid-19) Pandemic

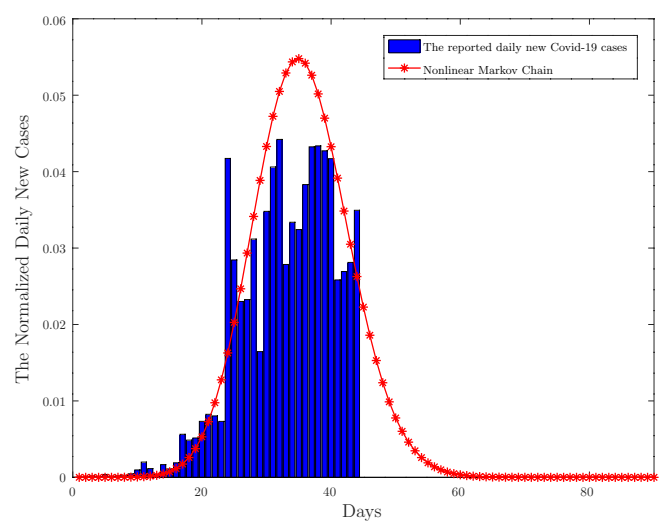

(a) Germany

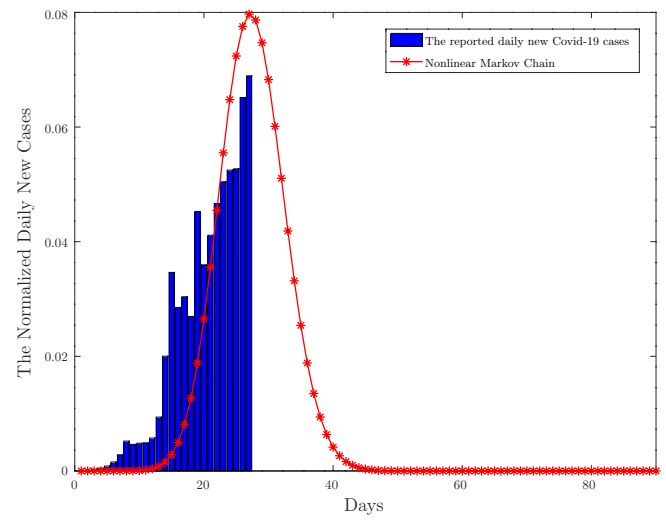

(c) Turkey

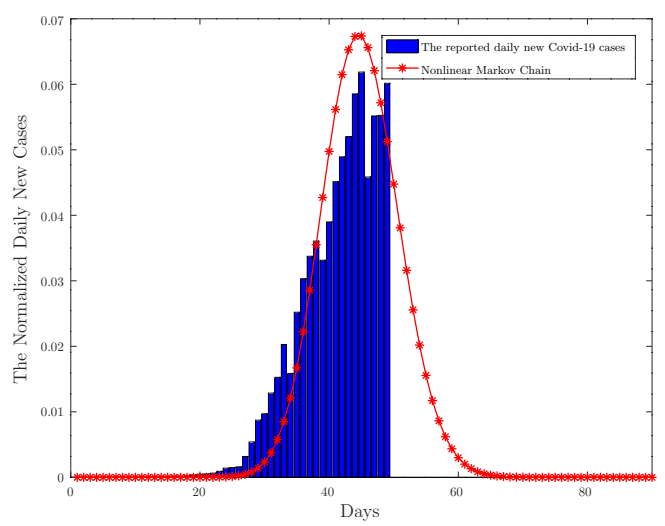

(b) USA

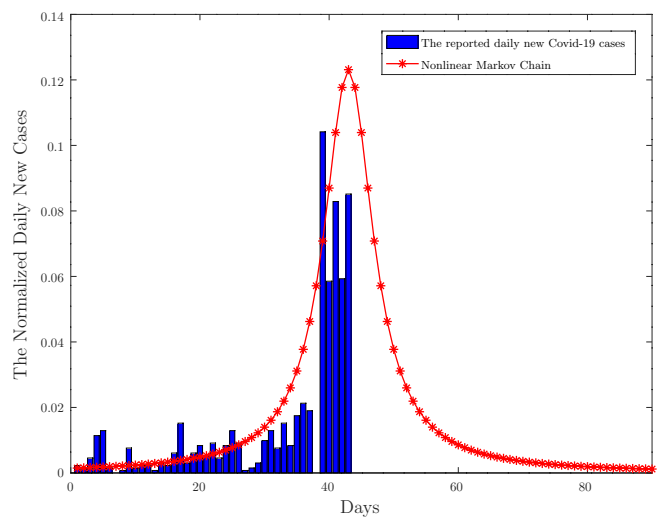

(d) Kuwait

Figure 4: The daily number of new Covid-19 cases 
medRxiv preprint doi: https://doi.org/10.1101/2020.04.21.20073668; this version posted April 24, 2020. The copyright holder for this preprint (which was not certified by peer review) is the author/funder, who has granted medRxiv a license to display the preprint in perpetuity.

All rights reserved. No reuse allowed without permission.

Nonlinear Markov Chain Modelling of the Novel Coronavirus (Covid-19) Pandemic

Table 2: lag - $k$ parameters of the countries

\begin{tabular}{|c|c|c|c|c|c|c|c|c|}
\hline & China & Italy & Spain & France & UK & Germany & USA & Turkey \\
\hline$l a g-k$ & 6 & 1 & 1 & 3 & 1 & 5 & 1 & 1 \\
\hline
\end{tabular}

$$
R_{x, y}=\frac{\sum_{i=1}^{n}\left(x_{i}-\bar{x}\right)\left(y_{i}-\bar{y}\right)}{\sqrt{\sum_{i=1}^{n}\left(x_{i}-\bar{x}\right)^{2} \sum_{i=1}^{n}\left(y_{i}-\bar{y}\right)^{2}}}
$$

where $\bar{x}$ and $\bar{y}$ are the expected values of the sequences of $x$ and $y$, respectively.

The value of $l a g-k$ can be considered as the time-shift between the daily number of the Covid-19 cases and the daily number of deaths. Therefore, the increases in lag $-k$ parameter shows that the corresponding country has detected the infected people earlier. Moreover, it might be a positive sign of the health system in such a country. There are only 2 reported dead cases in Kuwait up to now, hence State of Kuwait is not listed in Table 2.

\section{Conclusion}

In this paper, an nonlinear Markov chain model is proposed in order to analyse and to understand the novel coronavirus (Covid-19) pandemic. The data obtained from China was used to build up the presented model. Then, the proposed nonlinear Markov chain model is employed to predict the daily new Covid-19 cases among some countries. According to the results, the proposed model can efficiently capture the general behaviour the Covid-19 pandemic dispersion. Please note that, all the reported data including the daily number of new Covid-19 cases, the daily number of deaths, the number of the daily Covid-19 test are all assumed as correct. The model might need to be refined when a more reliable and detailed data is available.

\section{References}

[1] Covid-19 coronavirus pandemic. https://www.worldometers.info/coronavirus/. Accessed: 2020-4-12.

[2] Mapping 2019-ncov. https://systems.jhu.edu/research/public-health/ncov/. Accessed: 2020-4-12.

[3] Henri Berthiaux, Khadija Marikh, V Mizonov, D Ponomarev, and E Barantzeva. Modeling continuous powder mixing by means of the theory of markov chains. Particulate Science and Technology, 22(4):379-389, 2004.

[4] Muammer Catak, Nursin Bas, Kevin Cronin, John J Fitzpatrick, and Edmond P Byrne. Discrete solution of the breakage equation using markov chains. Industrial \& Engineering Chemistry Research, 49(17):8248-8257, 2010.

[5] Sheryl L Chang, Nathan Harding, Cameron Zachreson, Oliver M Cliff, and Mikhail Prokopenko. Modelling transmission and control of the covid-19 pandemic in australia. arXiv preprint arXiv:2003.10218, 2020.

[6] Matteo Chinazzi, Jessica T Davis, Marco Ajelli, Corrado Gioannini, Maria Litvinova, Stefano Merler, Ana Pastore y Piontti, Kunpeng Mu, Luca Rossi, Kaiyuan Sun, et al. The effect of travel restrictions on the spread of the 2019 novel coronavirus (covid-19) outbreak. Science, 2020. 
medRxiv preprint doi: https://doi.org/10.1101/2020.04.21.20073668; this version posted April 24, 2020. The copyright holder for this preprint (which was not certified by peer review) is the author/funder, who has granted medRxiv a license to display the preprint in perpetuity. All rights reserved. No reuse allowed without permission.

Nonlinear Markov Chain Modelling of the Novel Coronavirus (Covid-19) Pandemic

[7] Marius Gilbert, Giulia Pullano, Francesco Pinotti, Eugenio Valdano, Chiara Poletto, Pierre-Yves Boëlle, Eric d'Ortenzio, Yazdan Yazdanpanah, Serge Paul Eholie, Mathias Altmann, et al. Preparedness and vulnerability of african countries against importations of covid-19: a modelling study. The Lancet, 395(10227):871-877, 2020.

[8] Diego Giuliani, Maria Michela Dickson, Giuseppe Espa, and Flavio Santi. Modelling and predicting the spread of coronavirus (covid-19) infection in nuts-3 italian regions. arXiv preprint arXiv:2003.06664, 2020.

[9] Mark Jit, Thibaut Jombart, Emily Nightingale, Akira Endo, Sam Abbott, and William John Edmunds. Estimating number of cases and spread of coronavirus disease 2019 (covid-19) in the united kingdom using critical care admissions, february to march 2020. medRxiv, 2020.

[10] Gunter Kampf, Daniel Todt, Stephanie Pfaender, and Eike Steinmann. Persistence of coronaviruses on inanimate surfaces and its inactivation with biocidal agents. Journal of Hospital Infection, 2020.

[11] Adam J Kucharski, Timothy W Russell, Charlie Diamond, Yang Liu, John Edmunds, Sebastian Funk, Rosalind M Eggo, Fiona Sun, Mark Jit, James D Munday, et al. Early dynamics of transmission and control of covid-19: a mathematical modelling study. The lancet infectious diseases, 2020.

[12] World Health Organization. Coronavirus disease 2019 (covid-19)situation report - 82, 11 April 2020.

[13] Ashleigh R Tuite, David N Fisman, and Amy L Greer. Mathematical modelling of covid-19 transmission and mitigation strategies in the population of ontario, canada. CMAJ, 2020.

[14] Jiancong Wang, Mouqing Zhou, and Fangfei Liu. Reasons for healthcare workers becoming infected with novel coronavirus disease 2019 (covid-19) in china. The Journal of Hospital Infection, 2020. 